\title{
Establishing the Tolerability to Turkeys of Nonanoic Acid at Practical Levels of Use as a Feed Flavoring
}

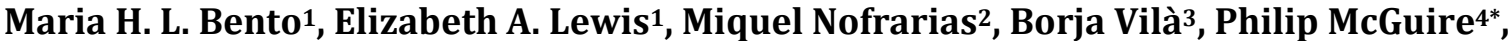 Kurt Richardson ${ }^{4}$}

${ }^{1}$ NutraSteward, Pembroke Dock, UK

${ }^{2} \mathrm{CReSA}$-Animal Health, IRTA, Bellaterra, Spain

${ }^{3}$ Animal Nutrition, IRTA, Constantí, Spain

${ }^{4}$ Anitox, Wellingborough, UK

Email: *pmcguire@anitox.com

How to cite this paper: Bento, M.H.L., Lewis, E.A., Nofrarias, M., Vilà, B., McGuire, P. and Richardson, K. (2021) Establishing the Tolerability to Turkeys of Nonanoic Acid at Practical Levels of Use as a Feed Flavoring. Open Journal of Animal Sciences, 11, 422-439. https://doi.org/10.4236/ojas.2021.113030

Received: February 26, 2021

Accepted: June 22, 2021

Published: June 25, 2021

Copyright $\odot 2021$ by author(s) and Scientific Research Publishing Inc. This work is licensed under the Creative Commons Attribution International License (CC BY 4.0).

http://creativecommons.org/licenses/by/4.0/

\begin{abstract}
Objective: Nonanoic acid (NA) is one of a series of straight-chain aliphatic alcohols, aldehydes, acids and their derivatives with a well-documented history of use as a synthetic flavoring in human food. As part of a safety evaluation of NA for use as a flavoring in animal feed, an experiment was conducted to evaluate the ability of turkeys to tolerate NA at levels relevant to practical feeding practices. Materials and Methods: A total of 594-day-old BUT Premium turkeys (300 males and 294 females) were allocated at random to 40 floor pens containing either 15 males or 13 to 15 females. Poults were fed one of 4 treatment diets in crumble ( 0 to 14 days) or pellet (15 to 59 days) form containing 0 (control), 100, 300 or $1000 \mathrm{mg} \mathrm{NA} / \mathrm{kg}$ complete feed for 59 days. General health and performance were monitored for the duration of the study. At days 57 and 59 of age, blood samples were taken and birds were sacrificed and necropsied for histopathological examination of the digestive tract. Significant differences were considered at $P \leq 0.05$ and near-significant trends at $P \leq 0.10$. Results: NA had no effect on mortality $\left(P \chi^{2}=0.54\right)$, average daily feed intake (ADFI) $(P=0.11)$, average daily gain (ADG) $(P=0.12)$ or feed conversion ratio (FCR) $(P=0.45)$ in poults over the 56 -day feeding period. No treatment-related effects on blood parameters or tissue pathology were observed. Conclusion: The results of the study support the safety and tolerance of NA to turkeys at dietary levels of up to $1000 \mathrm{mg} / \mathrm{kg}$ which will provide a considerable margin of safety compared to anticipated practical conditions of use as a feed flavoring.
\end{abstract}




\section{Keywords}

Turkey, Flavoring, Nonanoic Acid, Safety

\section{Introduction}

Nonanoic acid (NA) is one of a group of straight-chain aliphatic alcohols, aldehydes, acids and their derivatives with an established history of safe use as synthetic flavoring in human food [1] [2] [3]. It is a naturally occurring nine-carbon fatty acid which has been detected in a range of plants, fruit and vegetables at varying levels [4] [5]. In addition to its flavoring function in food, it is recognized to act as a fragrance and skin-conditioning agent in cosmetics [6].

Many established food flavorings can exhibit the same function in feed, and NA along with other structurally related substances is authorized for use for all animal species in Europe [7]. However, to date there is no regulatory acceptance of NA for use as a feed flavoring in the United States (U.S.). Feed flavorings play an important role in helping to mitigate the physical, physiological and environmental factors which contribute to reduced feed intake and growth performance by poultry and market demand for such substances is reported to be increasing steadily [8] [9]. Therefore, there is value in expanding the range of feed flavorings available to the poultry industry in the U.S.

In 2013, the European Food Safety Authority (EFSA) conducted an evaluation of the safety of NA and other straight-chain aliphatic alcohols, aldehydes, acids and their derivatives for use in feed and derived an acceptable level of intake of $10 \mathrm{mg} / \mathrm{kg}$ complete feed (12\% moisture) for broilers and laying hens, and 18 $\mathrm{mg} / \mathrm{kg}$ complete feed (12\% moisture) for turkeys on the basis of available toxicological information on members of this homologous series [10]. Extrapolation of findings from toxicology studies on laboratory animals to poultry is limited by the physiological differences between species, and the safe levels of 10 and $18 \mathrm{mg} / \mathrm{kg}$ complete feed (12\% moisture) for chickens and turkeys, respectively were calculated by employing a significant margin of safety of 200 to a No-Observed-Adverse-Effect-Level (NOAEL) of $120 \mathrm{mg} / \mathrm{kg}$ body weight/day derived from an 11-week study in rats using the structurally-related aldehyde, acetaldehyde and adjusting for FI and BW of the poultry species. No data in poultry, or livestock generally, were available to provide target animal-specific evidence of the safety of NA or the group of structurally-related substances for use as feed flavorings and allow a higher safe level of use to be derived. These limitations have practical implications, with significantly higher amounts of NA ( $>25$ $\mathrm{mg} / \mathrm{kg}$ complete feed) than the safe levels of 10 and $18 \mathrm{mg} / \mathrm{kg}$ complete feed (12\% moisture) allocated by EFSA potentially being required to offset the taste of less appealing substances in premixtures and feeds used in poultry nutrition. The only study to our knowledge in the published literature in which poultry were fed NA is a 29-day feeding trial in 7- to 21-day-old broiler chicks fed diets 
containing the flavoring at 0 or $30,000 \mathrm{mg} / \mathrm{kg}$ complete feed [11]. Feed intake and BW were reported to decrease by $50 \%$ in broilers fed the diets containing NA and mortality was higher. The level of supplementation in this study far exceeds practical flavoring use (i.e., $30,000 \mathrm{mg} / \mathrm{kg}$ complete feed vs. $25 \mathrm{mg} / \mathrm{kg}$ complete feed) and the results are not relevant to an assessment of the safety of NA as a feed flavoring.

The objective of this study was to evaluate the ability of growing turkeys to tolerate NA at dietary levels relevant to potential commercial feeding practices. A comprehensive set of endpoints, including general health, performance, production, routine blood parameters and tissue pathology were measured in order to meet the generally accepted requirements of regulatory authorities worldwide for assessing the safety of feed ingredients [12] [13]. Treatment levels were chosen to allow a margin of safety to be calculated compared to practical feeding levels in poultry nutrition.

\section{Materials and Methods}

\subsection{Test Materials}

Nonanoic acid (min. 98.5\%) was supplied by OXEA (Someren, Netherlands) as a colorless oily liquid. The corresponding amount of NA was first mixed with $1 \mathrm{~kg}$ of soya oil and then sprayed onto mash feed which was then mixed for another 6 minutes. The amount of NA mixed with soya oil to generate the feed for treatments 1 to 4 was $0,17.5,52.5$ or $175 \mathrm{~g} / \mathrm{kg}$ soya oil, respectively for the starter 1 diet; $0,25,75$ or $250 \mathrm{~g} / \mathrm{kg}$ soya oil, respectively for the starter 2 diet; $0,75,225$ or $750 \mathrm{~g} / \mathrm{kg}$ soya oil, respectively for the grower 1 diet; and $0,100,300$ or $1000 \mathrm{~g} / \mathrm{kg}$ soya oil, respectively for the grower 2 diet.

\subsection{Welfare}

The study was conducted at the trial facility of IRTA (Constanti, Spain). Animals were raised and treated in accordance with European Commission Recommendations 2007/526/EC and Directive 2010/63/EU [14] [15] pertaining to the protection, care and accommodation of animals used for experimental and other scientific purposes. The protocol for the animal study was reviewed and approved by the Institutional Animal Care and Use Committee prior to initiation.

\subsection{Animals and Housing}

Prior to the start of the study, birds were examined for any signs of illness or injury and only healthy birds were included in this study. A total of 594 day-old BUT Premium turkeys ( 300 male and 294 female) were randomly assigned to 40 floor pens $\left(2.94 \mathrm{~m}^{2}\right.$ each pen) and distributed to 4 treatments with 10 replicates, consisting of 5 replicate pens with 15 male birds and 5 replicate pens with $13-15$ female birds. The bird density at the end of the study was less than $30 \mathrm{~kg} / \mathrm{m}^{2}$ [16]. Fresh wood shavings were added to the pens at the start of the study. The lighting program was $24 \mathrm{~h}$ light for 0 - 2 days, $18 \mathrm{~h}$ light for $3-7$ days, and $14 \mathrm{~h}$ 
light for 15 - 59 days of age. There was one infrared gas brooder heater per pen. The rooms were equipped with forced ventilation. The temperature inside the rooms was at $32^{\circ} \mathrm{C}$ to $34^{\circ} \mathrm{C}$ from 0 to 2 days, $27^{\circ} \mathrm{C}$ to $30^{\circ} \mathrm{C}$ from 3 to 7 days, and was then decreased by $3^{\circ} \mathrm{C}$ per week until $21^{\circ} \mathrm{C}$ was reached.

\subsection{Diets}

Corn-soybean meal based diets, free of antibiotic growth promoters and coccidiostats, were formulated to meet the nutrient requirements recommended by Aviagen for the turkey breed used (BUT Premium) [17] (Table 1). Diets were fed ad libitum as pelleted crumble (0 to 14 days) or pellet form (15 to 59 days), respectively. There were four diets phases, as follows, 1) starter periods: 0 to 14 and 15 to 28 days; and 2) grower periods: 29 to 42 and 43 to 59 days.

Table 1. Composition of the diets, calculated and analyzed nutrient composition of the diets as fed.

\begin{tabular}{|c|c|c|c|c|}
\hline \multirow{2}{*}{ Items } & \multicolumn{4}{|c|}{ Diet phase } \\
\hline & 0 to 14 days & 15 to 28 days & 29 to 42 days & 43 to 59 days \\
\hline \multicolumn{5}{|l|}{ Ingredients composition (\%) } \\
\hline Maize & 41.46 & 47.24 & 51.76 & 56.85 \\
\hline Soya bean meal, $48 \% \mathrm{CP}$ & 50.41 & 45.30 & 40.92 & 36.48 \\
\hline Soybean oil & 2.44 & 2.05 & 2.18 & 1.84 \\
\hline Calcium carbonate & 0.73 & 0.66 & 0.59 & 0.52 \\
\hline Dicalcium phosphate & 3.02 & 2.89 & 2.77 & 2.59 \\
\hline Sodium chloride & 0.19 & 0.19 & 0.19 & 0.20 \\
\hline L-Lysine HCL & 0.37 & 0.32 & 0.30 & 0.27 \\
\hline DL-Methionine & 0.31 & 0.26 & 0.22 & 0.19 \\
\hline L-Threonine & 0.09 & 0.08 & 0.07 & 0.06 \\
\hline L-Tryptophan & - & - & - & 0.09 \\
\hline Vitamin-mineral premix $^{1}$ & 1.00 & 1.00 & 1.00 & 1.00 \\
\hline \multicolumn{5}{|c|}{ Calculated nutrient composition (\%, except if otherwise stated) } \\
\hline Metabolisable energy (kcal/kg) & 2775 & 2800 & 2850 & 2875 \\
\hline Dry Matter & 86.2 & 86.2 & 86.3 & 86.4 \\
\hline Crude protein & 27.70 & 25.60 & 23.80 & 22.10 \\
\hline Crude fiber & 2.60 & 2.50 & 2.50 & 2.40 \\
\hline Ash & 8.00 & 7.60 & 7.20 & 6.70 \\
\hline Digestible Lys & 1.76 & 1.60 & 1.47 & 1.34 \\
\hline Digestible SAA & 1.14 & 1.05 & 0.97 & 0.90 \\
\hline Digestible Thr & 1.02 & 0.94 & 0.87 & 0.80 \\
\hline $\mathrm{Ca}$ & 1.39 & 1.32 & 1.25 & 1.16 \\
\hline $\mathrm{P}$ & 0.95 & 0.91 & 0.87 & 0.83 \\
\hline
\end{tabular}




\section{Continued}

\begin{tabular}{ccccc}
\hline Non phytic P & 0.68 & 0.65 & 0.62 & 0.58 \\
Analyzed nutrient composition (\%) & & & & \\
Dry Matter & 88.58 & 88.65 & 89.0 & 88.65 \\
Crude Protein & 27.48 & 25.95 & 23.68 & 21.85 \\
Ether Extract & 4.70 & 4.43 & 4.55 & 4.38 \\
Ash & 7.18 & 7.03 & 6.68 & 6.18 \\
\hline
\end{tabular}

${ }^{1}$ Provided per one kilogram of feed: vitamin A (retinyl acetate), 10,000 IU; vitamin $\mathrm{B}_{1}$ (thiamine mononitrate), $1.7 \mathrm{mg}$; vitamin $\mathrm{B}_{2}, 8.6 \mathrm{mg}$; vitamin $\mathrm{B}_{6}, 4.7 \mathrm{mg}$; calcium pantothenate, $15.2 \mathrm{mg}$; vitamin $\mathrm{B}_{12}, 0.050 \mathrm{mg}$; nicotinic acid, $67 \mathrm{mg}$; vitamin $\mathrm{D}_{3}, 3500 \mathrm{IU}$; vitamin $\mathrm{E}$ (dl-alpha tocopherol), $33 \mathrm{IU}$; folic acid, $1.5 \mathrm{mg}$; vitamin $\mathrm{K}_{3}$ (menadione sodium bisulphate), $3 \mathrm{mg}$; biotin, $0.25 \mathrm{mg} ; \mathrm{Cu}\left(\mathrm{CuSO}_{4} \cdot 5 \mathrm{H}_{2} \mathrm{O}\right), 15 \mathrm{mg} ; \mathrm{Fe}\left(\mathrm{FeSO}_{4} \cdot \mathrm{H}_{2} \mathrm{O}\right)$, $65 \mathrm{mg} ; \mathrm{Mn}(\mathrm{MnO}), 80 \mathrm{mg} ; \mathrm{Zn}(\mathrm{ZnO}), 85 \mathrm{mg} ; \mathrm{I}\left(\mathrm{Ca}\left(\mathrm{IO}_{3}\right)_{2}\right), 1.5 \mathrm{mg}$; Se $\left(\mathrm{Na}_{2} \mathrm{SeO}_{3}\right), 0.20 \mathrm{mg} ; \mathrm{MgO}, \mathrm{NaHCO}_{3}$, $\mathrm{NaCl}$ and $\mathrm{CaCO}_{3}$ as carriers.

\subsection{Experimental Design and Dietary Treatments}

The experimental design was a $2 \times 4$ factorial randomized complete block design with two fixed factors, consisting of dietary treatment (NA) and sex and a random factor (block $=$ replicate location). The dietary treatments were, a control diet (treatment 1) and a control diet supplemented with $\mathrm{NA}$ at $100 \mathrm{mg} / \mathrm{kg}$ (treatment 2), $300 \mathrm{mg} / \mathrm{kg}$ (treatment 3) or $1000 \mathrm{mg} / \mathrm{kg}$ (treatment 4), respectively. All treatments were color-coded (blind treatments), so neither product names nor dosages were visible to the daily animal care monitor.

\subsection{Parameters Measured}

Diets were analyzed for nutrient content by IRTA Animal Nutrition Laboratory (Constanti, Spain) according to Association of Official Analytical Chemists (AOAC) methods [18]: dry matter (oven drying for $4 \mathrm{~h}$ at $103^{\circ} \mathrm{C}$; AOAC 925.09), ash (by incineration at $550^{\circ} \mathrm{C}$ for $3 \mathrm{~h}$; AOAC 923.03), crude protein (Dumas method using nitrogen/protein analyzer FP528, Leco; AOAC 968.06), fat (ether extract using Buchi Extraction System B811; AOAC 920.39).

Nonanoic acid (NA) levels in the treatment diets were analyzed by gas chromatography-mass spectrometry (GC-MS) using a Thermo Trace Ultra GC with split/splitless injection and DSOII mass spectrometer. Feed samples were ground to a homogeneous powder followed by extraction of NA using dichloromethane prior to analysis. The concentration of NA in the diets was calculated against a freshly prepared calibration standard curve using nonanoic acid- $d_{17}$ as the internal standard. The method (TM-665) was developed and internally validated by RSSL (Reading, UK).

General health status and mortality were monitored during the study. The birds were observed daily by animal supervisors and Veterinarian Surgeons inspected the birds at least once during the study.

Feed intake and body weights were recorded at days 28 and 56. Average daily feed intake (ADFI), average daily gain (ADG) and feed conversion ratio (FCR) for each pen were calculated for 0 to 28,29 to 56 and 0 to 56 days, respectively. 
At 57 and 59 days of age, blood was sampled by cardiac puncture from one randomly selected bird per replicate and per day ( 5 males and 5 females sampled per treatment and day). Samples from each bird were taken in two separate tubes $(\geq 0.6 \mathrm{ml}$ of blood in a tube containing EDTA and $\geq 1.5 \mathrm{ml}$ of blood in a tube containing serum gel S) and sent refrigerated for analysis of hematological and clinical chemistry parameters at Laboratorios Echevarne (Spain). Flow cytometry (Cell Dyn 3700) and manual observation was used for determination of hematological parameters, specifically red blood cells (erythrocytes), hemoglobin (HGB), mean corpuscular hemoglobin concentration (MCHC), mean corpuscular hemoglobin $(\mathrm{MCH})$, packed cell volume, mean corpuscular volume (MCV), hematocrit (HCT), white blood cell count, white blood cell differentials (segmented neutrophils, banded neutrophils, lymphocytes, monocytes and eosinophils). Clinical chemistry parameters, alkaline phosphatase (ALP), alanine aminotransferase (ALT), aspartate aminotransferase (AST), gamma glutamyl transferase (GGT), uric acid, total protein (TP) and albumin were determined by UV-Visible Spectrophotometry (Olympus AU5802).

The same birds were euthanized by pentobarbital dosing and necropsied for pathological assessment. For each bird, a complete necropsy was carried out by a Veterinarian Pathologist at the farm (observation of external aspect, abdominal cavity, thoracic cavity) and macroscopic findings were recorded. Weight of liver, spleen and kidneys were also determined. Subsequent to gross pathology examination, samples of liver, spleen, kidney and gastrointestinal tract lesions were collected and fixed by immersion in 10\% neutral-buffered formalin for lesion assessment under a light microscope at IRTA-CReSA laboratories (Bellaterra, Spain).

\subsection{Statistical Methods}

Continuous variables were analyzed using ANOVA by Mixed and General Linear Models of SAS [19]. Differences between treatments (NA level) were compared using the Tukey's post-hoc test according to the following statistical model.

$$
Y_{i j k}=\mu+\text { block }_{i}+\text { treatment }_{j}+\operatorname{sex}_{k}+\text { treatment }_{j} \times \operatorname{sex}_{k}+e_{i j k}
$$

$Y_{i j k}=$ dependent variable

$\mu=$ overall mean

block $_{i}=$ effect of block $($ random $)(i=1 \ldots 10)$

treatment $_{j}=$ effect of treatment $($ fixed $)(j=1 \ldots 4)$

$\operatorname{sex}_{k}=$ effect of sex (fixed) ( $k=$ male or female)

$e_{i j k}=$ residual error of the experimental unit

To investigate the NA treatment level response, linear and quadratic effects were tested over the whole range of NA inclusion (0 to $1000 \mathrm{mg} / \mathrm{kg}$ ). Significant differences were considered at $P \leq 0.05$ and near-significant trends at $P \leq 0.10$.

Mortality data was analyzed using non-parametric one-way ANOVA (KruskalWallis test). The pen was the experimental unit. For the blood parameters, the 
average per replicate was used in the Analysis of Variance.

\section{Results}

\subsection{Feed Analysis}

The analyzed NA content measured in representative samples of the diets offered to birds were $7 \mathrm{mg} / \mathrm{kg}$ (treatment 1), $62 \mathrm{mg} / \mathrm{kg}$ (treatment 2), $202 \mathrm{mg} / \mathrm{kg}$ (treatment 3 ) and $630 \mathrm{mg} / \mathrm{kg}$ (treatment 4 ). Compared to target values, recovery of NA from the treatment diets was $62.0 \%$ (treatment 2), 67.3\% (treatment 3), and $63.0 \%$ (treatment 4 ), respectively. The analyzed values of NA in the treatment diets broadly confirmed the inclusion of target levels.

\subsection{Health Status}

The health of the birds was maintained throughout the study and no adverse effects were noted. Total mortality/cull ratio at day 56 was 13/594 birds (2.2\%) (or $4 / 594(0.7 \%)$ if excluding first week starve outs) and no deaths were related to treatment $(P=0.54)$. The number of the first week starve outs was higher in the group fed $300 \mathrm{mg} \mathrm{NA} / \mathrm{kg}$ complete feed as-fed (treatment 3 ) relative to the control group (treatment 1), but were not attributed to treatment on the basis that 6 of the 9 birds that died weighed less upon arrival from the hatchery. Of the other 3 birds, 2 weighed only $2 \mathrm{~g}$ more than arrival, and one bird increased in weight ( $80 \mathrm{~g}$ at death) but only represented $57 \%$ of the breed standard when it died at day 6. There were only 2 starve-outs in the group fed NA at $1000 \mathrm{mg} / \mathrm{kg}$ complete feed as-fed (treatment 4$)$ which was not different $(P=0.15)$ when compared to the control group (treatment 1).

\subsection{Growth Performance}

There was no interaction between sex and NA supplementation on performance variables during any phase ( 0 to 28,28 to 56 or 0 to 56 days) of the study. During the starter periods from 0 to 28 days, there was an effect of sex $(P<0.001)$ on all performance variables (Table 2) with males outperforming females by $10 \%$ to $12 \%$ based on mean $\mathrm{BW}, \mathrm{ADG}$ and $\mathrm{ADFI}$, and displaying a $2 \%$ improvement in FCR. Body weight of males was according to breed standard but females weighed 5\% more than standard at 28 days. A quadratic response $(P=0.03)$ was observed with increasing dietary levels of the fatty acid for ADFI, which was numerically higher $(P=0.11)$ for all NA treatment levels $(100,300$, and 1000 $\mathrm{mg} / \mathrm{kg}$ ) compared to the control group.

The same effect of sex $(P<0.001)$ on performance variables was observed during the grower periods from 28 to 56 days (Table 3 ) with males outperforming females by $15 \%$ to $16 \%$ based on mean BW, ADG and ADFI, although there was no improvement in FCR. The BW of males was $97 \%$ of breed standard and females weighed $9 \%$ more than standard at day 56 . No differences were observed among treatment levels over the grower period, except for ADFI for which there was a linear increase $(P=0.01)$ with dietary supplementation of NA. ADFI was 
Table 2. Effects of NA and sex on BW, ADG, ADFI and FCR for 0 to 28 and 29 to 56 days of age.

\begin{tabular}{|c|c|c|c|c|c|c|c|c|c|}
\hline & & \multicolumn{4}{|c|}{ Performance, 0 to 28 days } & \multicolumn{4}{|c|}{ Performance, 29 to 56 days } \\
\hline & & $\begin{array}{l}\text { BW } \\
(\mathrm{g})\end{array}$ & $\begin{array}{c}\text { ADG } \\
\text { (g/day) }\end{array}$ & $\begin{array}{c}\text { ADFI } \\
\text { (g/day) }\end{array}$ & $\begin{array}{l}\text { FCR } \\
\text { (g:g) }\end{array}$ & $\begin{array}{l}\text { BW } \\
(\mathrm{g})\end{array}$ & $\begin{array}{c}\text { ADG } \\
\text { (g/day) }\end{array}$ & $\begin{array}{c}\text { ADFI } \\
\text { (g/day) }\end{array}$ & $\begin{array}{l}\text { FCR } \\
\text { (g:g) }\end{array}$ \\
\hline \multicolumn{10}{|l|}{ Effect of $N A$} \\
\hline Control $0 \mathrm{mg} / \mathrm{kg}$ & & 1095 & 37.0 & 52.9 & 1.430 & 4170 & 109.8 & $190.8^{\mathrm{Y}}$ & 1.738 \\
\hline $100 \mathrm{mg} / \mathrm{kg}$ & & 1091 & 36.9 & 53.1 & 1.440 & 4200 & 111.0 & $192.0^{\mathrm{XY}}$ & 1.731 \\
\hline $300 \mathrm{mg} / \mathrm{kg}$ & & 1121 & 37.9 & 54.8 & 1.445 & 4284 & 113.0 & $193.4^{\mathrm{XY}}$ & 1.712 \\
\hline $1000 \mathrm{mg} / \mathrm{kg}$ & & 1113 & 37.7 & 53.7 & 1.427 & 4284 & 113.3 & $198.8^{\mathrm{X}}$ & 1.755 \\
\hline$S E M$ & & 10.8 & 0.39 & 0.57 & 0.013 & 41.8 & 1.32 & 2.55 & 0.016 \\
\hline$P$-value (NA) & & 0.187 & 0.187 & 0.105 & 0.705 & 0.118 & 0.165 & 0.086 & 0.289 \\
\hline$P$-value (Linear) & & 0.195 & 0.195 & 0.422 & 0.581 & 0.062 & 0.071 & 0.012 & 0.257 \\
\hline$P$-value (Quadratic) & & 0.147 & 0.146 & 0.027 & 0.315 & 0.122 & 0.170 & 0.940 & 0.121 \\
\hline \multicolumn{10}{|l|}{ Effect of Sex } \\
\hline Female & & $1045^{\mathrm{n}}$ & $35.2^{\mathrm{n}}$ & $51.1^{\mathrm{n}}$ & $1.451^{\mathrm{m}}$ & $3946^{\mathrm{n}}$ & $103.6^{\mathrm{n}}$ & $179.7^{\mathrm{n}}$ & 1.735 \\
\hline Male & & $1165^{\mathrm{m}}$ & $39.5^{\mathrm{m}}$ & $56.1^{\mathrm{n}}$ & $1.420^{\mathrm{n}}$ & $4523^{\mathrm{m}}$ & $119.9^{\mathrm{m}}$ & $207.9^{\mathrm{m}}$ & 1.733 \\
\hline$S E M$ & & 7.6 & 0.27 & 0.40 & 0.009 & 33.5 & 1.15 & 2.32 & 0.011 \\
\hline$P$-value (Sex) & & $<0.001$ & $<0.001$ & $<0.001$ & 0.019 & $<0.001$ & $<0.001$ & $<0.001$ & 0.917 \\
\hline \multicolumn{10}{|l|}{ Effect of $N A \times$ Sex } \\
\hline \multirow[t]{2}{*}{ Control $0 \mathrm{mg} / \mathrm{kg}$} & Female & 1030 & 34.7 & 50.5 & 1.457 & 3854 & 100.9 & 175.2 & 1.738 \\
\hline & Male & 1160 & 39.4 & 55.2 & 1.403 & 4485 & 118.8 & 206.5 & 1.739 \\
\hline \multirow[t]{2}{*}{$100 \mathrm{mg} / \mathrm{kg}$} & Female & 1041 & 35.1 & 50.7 & 1.445 & 3968 & 104.5 & 181.7 & 1.741 \\
\hline & Male & 1142 & 38.7 & 55.6 & 1.436 & 4433 & 117.5 & 202.3 & 1.721 \\
\hline \multirow[t]{2}{*}{$300 \mathrm{mg} / \mathrm{kg}$} & Female & 1058 & 35.7 & 52.1 & 1.459 & 3969 & 103.9 & 177.9 & 1.712 \\
\hline & Male & 1183 & 40.2 & 57.5 & 1.431 & 4600 & 122.0 & 209.0 & 1.712 \\
\hline \multirow[t]{2}{*}{$1000 \mathrm{mg} / \mathrm{kg}$} & Female & 1051 & 35.4 & 51.1 & 1.443 & 3995 & 105.1 & 183.9 & 1.750 \\
\hline & Male & 1174 & 39.9 & 56.2 & 1.410 & 4573 & 121.4 & 213.8 & 1.761 \\
\hline$S E M$ & & 15.3 & 0.55 & 0.81 & 0.018 & 59.1 & 1.87 & 3.60 & 0.023 \\
\hline$P$-value (Interaction) & & 0.791 & 0.790 & 0.981 & 0.659 & 0.421 & 0.425 & 0.297 & 0.917 \\
\hline
\end{tabular}

$\mathrm{FCR}=$ feed conversion ratio; $\mathrm{NA}=$ nonanoic acid; $\mathrm{SEM}=$ standard error of the mean. ${ }^{\mathrm{xy}}$ Means within variable and factor with no common superscripts differed significantly at $P \leq 0.10$ (with Tukey's adjustment). ${ }^{\mathrm{mn}}$ Means within variable and factor with no common superscripts differed significantly at $P \leq 0.05$.

Table 3. Effects of NA and sex on turkey BW, ADG, ADFI and FCR from 0 to 56 days of age.

\begin{tabular}{ccccc}
\hline & \multicolumn{4}{c}{ Performance, 0 to 56 days } \\
\cline { 2 - 5 } & BW (g) & ADG (g/day) & ADFI (g/day) & FCR (g:g) \\
\hline $\begin{array}{c}\text { Effect of } N A \\
\text { Control } 0 \mathrm{mg} / \mathrm{kg}\end{array}$ & 4170 & 73.4 & 121.9 & 1.661 \\
\hline
\end{tabular}




\section{Continued}

\begin{tabular}{|c|c|c|c|c|c|}
\hline $100 \mathrm{mg} / \mathrm{kg}$ & & 4200 & 74.0 & 122.5 & 1.658 \\
\hline $300 \mathrm{mg} / \mathrm{kg}$ & & 4284 & 75.5 & 124.1 & 1.644 \\
\hline $1000 \mathrm{mg} / \mathrm{kg}$ & & 4284 & 75.5 & 126.2 & 1.673 \\
\hline SEM & & 41.8 & 0.75 & 1.43 & 0.012 \\
\hline$P$-value (NA) & & 0.118 & 0.118 & 0.114 & 0.451 \\
\hline$P$-value (Linear) & & 0.062 & 0.062 & 0.019 & 0.339 \\
\hline$P$-value (Quadratic) & & 0.122 & 0.122 & 0.580 & 0.204 \\
\hline \multicolumn{6}{|l|}{ Effect of Sex } \\
\hline Female & & $3946 n$ & $69.4 n$ & $115.4 \mathrm{n}$ & 1.662 \\
\hline Male & & $4523 \mathrm{~m}$ & $79.7 \mathrm{~m}$ & $132.0 \mathrm{~m}$ & 1.655 \\
\hline SEM & & 33.5 & 0.60 & 1.24 & 0.009 \\
\hline$P$-value (Sex) & & $<0.001$ & $<0.001$ & $<0.001$ & 0.582 \\
\hline \multicolumn{6}{|l|}{ Effect of NA $\times$ Sex } \\
\hline \multirow[t]{2}{*}{ Control 0 mg/kg } & Female & 3854 & 67.8 & 112.9 & 1.666 \\
\hline & Male & 4485 & 79.1 & 130.9 & 1.656 \\
\hline \multirow[t]{2}{*}{$100 \mathrm{mg} / \mathrm{kg}$} & Female & 3968 & 69.8 & 116.2 & 1.665 \\
\hline & Male & 4433 & 78.1 & 128.9 & 1.650 \\
\hline \multirow[t]{2}{*}{$300 \mathrm{mg} / \mathrm{kg}$} & Female & 3969 & 69.8 & 115.0 & 1.647 \\
\hline & Male & 4600 & 81.1 & 133.2 & 1.641 \\
\hline \multirow[t]{2}{*}{$1000 \mathrm{mg} / \mathrm{kg}$} & Female & 3995 & 70.3 & 117.4 & 1.671 \\
\hline & Male & 4573 & 80.6 & 135.0 & 1.674 \\
\hline SEM & & 59.1 & 1.05 & 2.02 & 0.017 \\
\hline$P$-value (Interaction) & & 0.421 & 0.421 & 0.415 & 0.956 \\
\hline
\end{tabular}

$\mathrm{FCR}=$ feed conversion ratio; $\mathrm{NA}=$ nonanoic acid; $\mathrm{SEM}=$ standard error of the mean. ${ }^{\mathrm{mn}}$ Means within variable and factor with no common superscripts differed significantly at $P \leq 0.05$.

$4 \%$ greater in birds fed NA at $1000 \mathrm{mg} / \mathrm{kg}$ complete feed as-fed relative to the control group. Considering the linear regression slopes, ADFI increased by $0.9 \mathrm{~g}$ and ADG by $0.3 \mathrm{~g}$ for every $100 \mathrm{mg}$ NA addition to the complete feed as-fed.

Over the entire study period of 0 to 56 days, there was an effect of $\operatorname{sex}(P<$ $0.001)$ on all performance variables (Table 4$)$ except FCR $(P=0.58)$ with males outperforming females by $14 \%$ to $16 \%$ based on mean BW, ADG and ADFI. No effects on BW $(P=0.12)$, ADG $(P=0.11)$, and ADFI $(P=0.45)$ were observed among NA groups $(0,100,300$, and $1000 \mathrm{mg} / \mathrm{kg})$. However, ADG and ADFI increased linearly with dietary supplementation of NA $(P=0.06$ and 0.02 , for ADG and ADFI, respectively). Considering the linear regression slopes, ADG and ADFI increased by 0.2 and $0.5 \mathrm{~g}$, respectively for every $100 \mathrm{mg} \mathrm{NA} / \mathrm{kg}$ addition to the complete feed as-fed.

\subsection{Blood Parameters}

There was no interaction between treatment and sex for any of the biochemical 
Table 4. Effects of NA and sex on selected blood chemistry parameters in turkeys at the end of the study.

\begin{tabular}{|c|c|c|c|c|c|c|c|}
\hline & & $\begin{array}{c}\text { ALP } \\
(U / L)\end{array}$ & $\begin{array}{c}\text { ALT } \\
(\mathrm{U} / \mathrm{L})\end{array}$ & $\begin{array}{c}\text { AST } \\
(\mathrm{U} / \mathrm{L})\end{array}$ & $\begin{array}{c}\mathrm{TP} \\
(\mathrm{g} / \mathrm{L})\end{array}$ & $\begin{array}{c}\text { Albumin } \\
(\mathrm{g} / \mathrm{L})\end{array}$ & $\begin{array}{l}\text { Uric acid } \\
(\mathrm{mg} / \mathrm{dL})\end{array}$ \\
\hline \multicolumn{8}{|l|}{ Effect of NA } \\
\hline \multicolumn{2}{|l|}{ Control $0 \mathrm{mg} / \mathrm{kg}$} & 2991 & $5.0^{\mathrm{x}}$ & 353 & 36.3 & 13.4 & $3.8^{\mathrm{xy}}$ \\
\hline \multicolumn{2}{|l|}{$100 \mathrm{mg} / \mathrm{kg}$} & 3128 & $4.4^{y}$ & 342 & 36.1 & 13.3 & $3.6^{\mathrm{y}}$ \\
\hline \multicolumn{2}{|l|}{$300 \mathrm{mg} / \mathrm{kg}$} & 3107 & $4.1^{\mathrm{y}}$ & 338 & 35.0 & 12.7 & $4.6^{\mathrm{x}}$ \\
\hline \multicolumn{2}{|l|}{$1000 \mathrm{mg} / \mathrm{kg}$} & 2934 & $4.3^{y}$ & 351 & 35.3 & 13.3 & $3.4^{\mathrm{y}}$ \\
\hline \multicolumn{2}{|l|}{$S E M$} & 98.9 & 0.16 & 11.4 & 0.64 & 0.24 & 0.23 \\
\hline \multicolumn{2}{|l|}{$P$-value (NA) } & 0.373 & $<0.001$ & 0.755 & 0.327 & $0.088^{\dagger}$ & 0.004 \\
\hline \multicolumn{2}{|l|}{$P$-value (Linear) } & 0.280 & 0.018 & 0.823 & 0.257 & 0.896 & 0.112 \\
\hline \multicolumn{2}{|l|}{$P$-value (Quadratic) } & 0.241 & $<0.001$ & 0.312 & 0.159 & 0.018 & 0.003 \\
\hline \multicolumn{8}{|l|}{ Effect of Sex } \\
\hline \multicolumn{2}{|l|}{ Female } & $2914^{\mathrm{N}}$ & 4.5 & 346 & 35.9 & $13.8^{\mathrm{m}}$ & $4.1^{\mathrm{M}}$ \\
\hline \multicolumn{2}{|l|}{ Male } & $3167^{\mathrm{M}}$ & 4.3 & 345 & 35.4 & $12.5^{\mathrm{n}}$ & $3.6^{\mathrm{N}}$ \\
\hline \multicolumn{2}{|l|}{ SEM } & 87.7 & 0.14 & 8.1 & 0.58 & 0.25 & 0.17 \\
\hline \multicolumn{2}{|l|}{$P$-value (Sex) } & 0.075 & 0.279 & 0.938 & 0.596 & 0.005 & 0.088 \\
\hline \multicolumn{8}{|l|}{ Effect of $N A \times$ Sex } \\
\hline \multirow[t]{2}{*}{ Control $0 \mathrm{mg} / \mathrm{kg}$} & Female & 2939 & 5.3 & 367 & 36.3 & 14.0 & 4.2 \\
\hline & Male & 3043 & 4.7 & 339 & 36.3 & 12.7 & 3.5 \\
\hline \multirow[t]{2}{*}{$100 \mathrm{mg} / \mathrm{kg}$} & Female & 2925 & 4.4 & 329 & 35.7 & 13.8 & 3.9 \\
\hline & Male & 3331 & 4.3 & 355 & 36.4 & 12.8 & 3.4 \\
\hline \multirow[t]{2}{*}{$300 \mathrm{mg} / \mathrm{kg}$} & Female & 2854 & 4.0 & 342 & 35.5 & 13.2 & 4.8 \\
\hline & Male & 3361 & 4.1 & 333 & 34.4 & 12.2 & 4.5 \\
\hline \multirow[t]{2}{*}{$1000 \mathrm{mg} / \mathrm{kg}$} & Female & 2936 & 4.4 & 348 & 36.0 & 14.3 & 3.5 \\
\hline & Male & 2932 & 4.1 & 354 & 34.6 & 12.2 & 3.2 \\
\hline \multicolumn{2}{|l|}{$S E M$} & 139.9 & 0.22 & 16.2 & 0.91 & 0.34 & 0.33 \\
\hline \multicolumn{2}{|c|}{$P$-value (Interaction) } & 0.165 & 0.354 & 0.414 & 0.549 & 0.173 & 0.854 \\
\hline
\end{tabular}

ALP = alkaline phosphatase; ALT = alanine aminotransferase; AST = aspartate aminotransferase; GGT = g-glutamine transpeptidase; $\mathrm{NA}=$ nonanoic acid; $\mathrm{TP}$ = total proteins; $\mathrm{SEM}=$ standard error of the mean. GGT: only 6 out of 80 birds did have values higher than the level of detection, $3 \mathrm{U} / \mathrm{L}$ (data not shown in table). ${ }^{x y}$ Means within variable and factor with no common superscripts differed significantly at $P \leq 0.05$ (with Tukey's adjustment). 'No significant differences among treatments with Tukey's adjustment $(P>$ $0.10)$. ${ }^{\mathrm{mn}}$ Means within variable and factor with no common superscripts differed significantly at $P \leq 0.05$. ${ }^{\mathrm{MN}}$ Means within variable and factor with no common superscripts differed significantly at $P \leq 0.10$.

variables evaluated (Table 5). In birds fed diets supplemented with NA (100, 300 , or $1000 \mathrm{mg} / \mathrm{kg})$, ALT concentrations were lower $(P<0.001)$ than for the control group. Uric acid displayed a quadratic response with higher values $(P=$ $0.004)$ for NA at $300 \mathrm{mg} / \mathrm{kg}$, but no differences were detected between birds fed NA supplemented diets at 100 or $1000 \mathrm{mg} / \mathrm{kg}$ relative to those fed the control diet. There was a trend to higher levels of uric acid $(P=0.09)$ in female than male 
Table 5. Effects of NA and sex on selected blood hematology parameters in turkeys at the end of the study.

\begin{tabular}{|c|c|c|c|c|c|c|c|}
\hline & & $\begin{array}{c}\text { MCHC } \\
(\mathrm{g} / \mathrm{dL})\end{array}$ & $\begin{array}{c}\mathrm{MCH} \\
\text { (pg) }\end{array}$ & $\begin{array}{c}\mathrm{MCV} \\
(\mathrm{fL})\end{array}$ & $\begin{array}{c}\mathrm{HCT} \\
(\%)\end{array}$ & $\begin{array}{l}\text { HGB } \\
(\mathrm{g} / \mathrm{dL})\end{array}$ & $\begin{array}{c}\text { Erythrocytes } \\
\left(\times 10^{6} / \mu \mathrm{L}\right)\end{array}$ \\
\hline \multicolumn{8}{|l|}{ Effect of $N A$} \\
\hline Control $0 \mathrm{mg} / \mathrm{kg}$ & & 37.0 & 56.8 & 154 & 37.1 & 13.7 & 2.4 \\
\hline $100 \mathrm{mg} / \mathrm{kg}$ & & 37.4 & 57.3 & 153 & 37.2 & 13.9 & 2.4 \\
\hline $300 \mathrm{mg} / \mathrm{kg}$ & & 36.8 & 56.6 & 154 & 36.7 & 13.5 & 2.4 \\
\hline $1000 \mathrm{mg} / \mathrm{kg}$ & & 37.3 & 57.1 & 153 & 36.2 & 13.5 & 2.4 \\
\hline$S E M$ & & 0.26 & 0.43 & 0.9 & 0.58 & 0.18 & 0.039 \\
\hline$P$-value (NA) & & 0.323 & 0.678 & 0.912 & 0.584 & 0.357 & 0.626 \\
\hline$P$-value (Linear) & & 0.530 & 0.826 & 0.634 & 0.186 & 0.252 & 0.248 \\
\hline$P$-value (Quadratic) & & 0.453 & 0.640 & 0.807 & 0.844 & 0.541 & 0.748 \\
\hline \multicolumn{8}{|l|}{ Effect of Sex } \\
\hline Female & & 37.0 & 56.9 & 154 & $37.6^{\mathrm{M}}$ & $13.9^{\mathrm{M}}$ & 2.4 \\
\hline Male & & 37.3 & 56.9 & 153 & $36.1^{\mathrm{N}}$ & $13.4^{\mathrm{N}}$ & 2.4 \\
\hline$S E M$ & & 0.18 & 0.31 & 0.7 & 0.47 & 0.15 & 0.035 \\
\hline$P$-value (Sex) & & 0.345 & 0.917 & 0.324 & 0.056 & 0.057 & 0.135 \\
\hline \multicolumn{8}{|l|}{ Effect of $N A \times$ Sex } \\
\hline \multirow[t]{2}{*}{ Control $0 \mathrm{mg} / \mathrm{kg}$} & Female & 37.1 & 56.4 & 152 & 37.6 & 13.9 & 2.5 \\
\hline & Male & 36.8 & 57.1 & 155 & 36.7 & 13.5 & 2.4 \\
\hline \multirow[t]{2}{*}{$100 \mathrm{mg} / \mathrm{kg}$} & Female & 37.4 & 57.5 & 154 & 37.8 & 14.1 & 2.5 \\
\hline & Male & 37.5 & 57.1 & 152 & 36.6 & 13.7 & 2.4 \\
\hline \multirow[t]{2}{*}{$300 \mathrm{mg} / \mathrm{kg}$} & Female & 36.7 & 56.9 & 155 & 38.1 & 13.9 & 2.5 \\
\hline & Male & 37.0 & 56.3 & 152 & 35.4 & 13.1 & 2.3 \\
\hline \multirow[t]{2}{*}{$1000 \mathrm{mg} / \mathrm{kg}$} & Female & 36.9 & 56.8 & 154 & 36.8 & 13.6 & 2.4 \\
\hline & Male & 37.8 & 57.3 & 152 & 35.7 & 13.5 & 2.4 \\
\hline$S E M$ & & 0.37 & 0.61 & 1.3 & 0.82 & 0.26 & 0.055 \\
\hline$P$-value (Interaction) & & 0.433 & 0.657 & $0.090^{\dagger}$ & 0.665 & 0.489 & 0.687 \\
\hline
\end{tabular}

$\mathrm{MCHC}=$ mean corpuscular hemoglobin concentration; $\mathrm{MCH}=$ mean corpuscular hemoglobin; $\mathrm{MCV}=$ mean corpuscular volume; $\mathrm{HTC}=$ hematocrit; $\mathrm{HGB}=$ hemoglobin; $\mathrm{NA}=$ nonanoic acid; $\mathrm{SEM}=$ standard error of the mean. ${ }^{M N}$ Means within variable and factor with no common superscripts differed significantly at $P \leq 0.10 .{ }^{\dagger}$ No significant differences among treatments with Tukey's adjustment $(P>0.10)$.

turkeys. Albumin levels were not different between birds fed NA supplemented diets compared to birds fed the control diet, but female birds exhibited higher concentrations than males $(P=0.005)$, especially in the group fed $1000 \mathrm{mg}$ $\mathrm{NA} / \mathrm{kg}$ complete feed as-fed. Only 6 out of 80 birds presented GGT values higher than detection levels ( $3 \mathrm{U} / \mathrm{L})$ and therefore, statistical analyses were not conducted on this blood parameter.

No interaction between sex and treatment was observed for any of the hema- 
tology parameters evaluated, except MCV (higher values for female than male in all NA levels except in the control group); however, means comparisons with Tukey's adjustment were all non-significant (Table 6 and Table 7). There were no treatment-related effects on hematology variables ( $P=0.10$ for basophils; $P>$ 0.3 for other variables), although female birds tended to display higher HCT and HGB values than male birds $(P=0.06)$.

\subsection{Tissue Pathology}

At necropsy, no treatment-related patterns in the incidence of visible lesions were observed. Minor incidences of hydropic hepatic degeneration in the liver were

Table 6. Effects of NA and sex on total and differential leukocytes counts in turkeys at the end of the study.

\begin{tabular}{|c|c|c|c|c|c|c|c|}
\hline & & $\begin{array}{l}\text { Leukocytes } \\
\left(\times 10^{3} / \mu \mathrm{L}\right)\end{array}$ & $\begin{array}{l}\text { Eosinophils } \\
\left(\times 10^{3} / \mu \mathrm{L}\right)\end{array}$ & $\begin{array}{l}\text { Basophils } \\
\left(\times 10^{3} / \mu \mathrm{L}\right)\end{array}$ & $\begin{array}{l}\text { Lymphocytes } \\
\qquad\left(\times 10^{3} / \mu \mathrm{L}\right)\end{array}$ & $\begin{array}{l}\text { Monocytes } \\
\left(\times 10^{3} / \mu \mathrm{L}\right)\end{array}$ & $\begin{array}{c}\text { Heterophils } \\
\left(\times 10^{3} / \mu \mathrm{L}\right)\end{array}$ \\
\hline \multicolumn{8}{|l|}{ Effect of $N A$} \\
\hline Control $0 \mathrm{mg} / \mathrm{kg}$ & & 26.0 & 0.57 & 1.9 & 9.5 & 0.40 & 13.6 \\
\hline $100 \mathrm{mg} / \mathrm{kg}$ & & 21.8 & 0.53 & 1.1 & 8.2 & 0.56 & 11.4 \\
\hline $300 \mathrm{mg} / \mathrm{kg}$ & & 23.2 & 0.50 & 0.95 & 9.0 & 0.60 & 12.1 \\
\hline $1000 \mathrm{mg} / \mathrm{kg}$ & & 24.2 & 0.52 & 1.1 & 8.5 & 0.47 & 13.6 \\
\hline$S E M$ & & 1.958 & 0.105 & 0.285 & 0.927 & 0.157 & 1.069 \\
\hline$P$-value (NA) & & 0.429 & 0.968 & 0.103 & 0.771 & 0.819 & 0.306 \\
\hline$P$-value (Linear) & & 0.977 & 0.824 & 0.309 & 0.669 & 0.964 & 0.423 \\
\hline$P$-value (Quadratic) & & 0.317 & 0.666 & 0.053 & 0.856 & 0.379 & 0.230 \\
\hline \multicolumn{8}{|l|}{ Effect of Sex } \\
\hline Female & & 22.5 & 0.48 & 1.3 & 8.3 & 0.48 & 12.0 \\
\hline Male & & 25.1 & 0.57 & 1.3 & 9.4 & 0.54 & 13.3 \\
\hline$S E M$ & & 1.689 & 0.085 & 0.202 & 0.657 & 0.111 & 0.958 \\
\hline$P$-value (Sex) & & 0.315 & 0.459 & 0.983 & 0.258 & 0.708 & 0.373 \\
\hline \multicolumn{8}{|l|}{ Effect of $N A \times$ Sex } \\
\hline \multirow[t]{2}{*}{ Control $0 \mathrm{mg} / \mathrm{kg}$} & Female & 25.9 & 0.51 & 2.5 & 9.1 & 0.28 & 13.6 \\
\hline & Male & 26.0 & 0.63 & 1.3 & 10.0 & 0.53 & 13.6 \\
\hline \multirow[t]{2}{*}{$100 \mathrm{mg} / \mathrm{kg}$} & Female & 19.1 & 0.42 & 0.84 & 7.3 & 0.81 & 9.7 \\
\hline & Male & 24.5 & 0.63 & 1.3 & 9.2 & 0.30 & 13.1 \\
\hline \multirow[t]{2}{*}{$300 \mathrm{mg} / \mathrm{kg}$} & Female & 20.6 & 0.35 & 0.67 & 8.6 & 0.34 & 10.7 \\
\hline & Male & 25.7 & 0.65 & 1.2 & 9.4 & 0.86 & 13.6 \\
\hline \multirow[t]{2}{*}{$1000 \mathrm{mg} / \mathrm{kg}$} & Female & 24.3 & 0.65 & 1.0 & 8.0 & 0.49 & 14.2 \\
\hline & Male & 24.1 & 0.39 & 1.3 & 9.0 & 0.45 & 13.0 \\
\hline$S E M$ & & 2.769 & 0.149 & 0.403 & 1.311 & 0.222 & 1.511 \\
\hline$P$-value (Interaction) & & 0.543 & 0.215 & 0.119 & 0.977 & 0.135 & 0.279 \\
\hline
\end{tabular}

$\mathrm{NA}=$ nonanoic acid; SEM = standard error of the mean. 
Table 7. Effects of NA and sex on mortality from 0 to 56 days of age ${ }^{1}$.

\begin{tabular}{|c|c|c|c|c|}
\hline & & \multicolumn{3}{|c|}{ Number of dead birds } \\
\hline & & 0 to 28 days & 29 to 56 days $^{2}$ & 0 to 56 days \\
\hline \multicolumn{5}{|l|}{ Effect of NA } \\
\hline Control $0 \mathrm{mg} / \mathrm{kg}$ & & 1 & 1 & 2 \\
\hline $100 \mathrm{mg} / \mathrm{kg}$ & & 1 & 0 & 1 \\
\hline $300 \mathrm{mg} / \mathrm{kg}$ & & 0 & 0 & 0 \\
\hline $1000 \mathrm{mg} / \mathrm{kg}$ & & 0 & 1 & 1 \\
\hline$P \chi^{2}$-value (NA) & & 0.562 & 0.562 & 0.539 \\
\hline \multicolumn{5}{|l|}{ Effect of Sex } \\
\hline Female & & 2 & 1 & 3 \\
\hline Male & & 0 & 1 & 1 \\
\hline$P \chi^{2}$-value (Sex) & & 0.152 & - & 0.298 \\
\hline \multicolumn{5}{|l|}{ Effect of $N A \times S e x$} \\
\hline \multirow[t]{2}{*}{ Control $0 \mathrm{mg} / \mathrm{kg}$} & Female & 1 & 0 & 1 \\
\hline & Male & 0 & 1 & 1 \\
\hline \multirow[t]{2}{*}{$100 \mathrm{mg} / \mathrm{kg}$} & Female & 1 & 0 & 1 \\
\hline & Male & 0 & 0 & 0 \\
\hline \multirow[t]{2}{*}{$300 \mathrm{mg} / \mathrm{kg}$} & Female & 0 & 0 & 0 \\
\hline & Male & 0 & 0 & 0 \\
\hline \multirow[t]{2}{*}{$1000 \mathrm{mg} / \mathrm{kg}$} & Female & 0 & 1 & 1 \\
\hline & Male & 0 & 0 & 0 \\
\hline$P \chi^{2}$-value (Interaction) & & 0.521 & 0.521 & 0.741 \\
\hline
\end{tabular}

NA, Nonanoic acid. ${ }^{1} P \chi^{2}$-value: data was analyzed using non-parametric one-way ANOVA (Kruskal-Wallis test). ${ }^{2}$ No statistical analysis performed for sex in the period 29 to 56 days because of the same number of dead birds in male and female.

reported (13 out of 20 birds in both 0 and $1000 \mathrm{mg} / \mathrm{kg}$ of NA) but these lesions were of mild to moderate intensity and showed no treatment-related response and thus were attributed to normal variation.

No interactions between sex and treatment were detected in absolute or relative weights of liver, spleen or kidneys (Table 8). NA treatment levels had no effect on absolute weights of liver $(P=0.61)$, spleen $(P=0.95)$ and kidneys $(P=$ $0.68)$, or in relative weights of spleen $(P=0.97)$ and kidneys $(P=0.34)$. Relative liver weight was affected by dietary NA level in a quadratic way $(P=0.049)$ with higher values reported in birds fed diets containing $100 \mathrm{mg} \mathrm{NA} / \mathrm{kg}$ compared to those fed $300 \mathrm{mg} \mathrm{NA} / \mathrm{kg}$ complete feed as-fed. Sex had an effect on relative weight of liver $(P<0.001$; higher for females), absolute and relative weights of spleen $(P<0.001$; lower for females), and on absolute weight of kidneys $(P<$ 0.001 , lower for females). 
Table 8. Effects of NA and sex on organ weight (g) and relative organ weight (\%) in turkeys at the end of the study.

\begin{tabular}{|c|c|c|c|c|c|c|c|c|}
\hline & & \multirow{2}{*}{$\begin{array}{l}\text { BW } \\
\text { (g) }\end{array}$} & \multicolumn{2}{|c|}{ Liver } & \multicolumn{2}{|c|}{ Spleen } & \multicolumn{2}{|c|}{ Kidney } \\
\hline & & & (g) & $(\%)^{1}$ & (g) & $(\%)^{1}$ & (g) & $(\%)^{1}$ \\
\hline \multicolumn{9}{|l|}{ Effect of NA } \\
\hline Control $0 \mathrm{mg} / \mathrm{kg}$ & & 4612 & 84.7 & $1.9^{\mathrm{xy}}$ & 4.5 & 0.096 & 26.9 & 0.581 \\
\hline $100 \mathrm{mg} / \mathrm{kg}$ & & 4530 & 84.1 & $1.9^{\mathrm{x}}$ & 4.5 & 0.099 & 27.2 & 0.599 \\
\hline $300 \mathrm{mg} / \mathrm{kg}$ & & 4763 & 81.2 & $1.7^{\mathrm{y}}$ & 4.6 & 0.097 & 28.0 & 0.587 \\
\hline $1000 \mathrm{mg} / \mathrm{kg}$ & & 4618 & 81.0 & $1.8^{x y}$ & 4.5 & 0.095 & 28.3 & 0.613 \\
\hline$S E M$ & & 100.0 & 2.41 & 0.043 & 0.266 & 0.006 & 0.92 & 0.013 \\
\hline$P$-value (NA) & & 0.433 & 0.605 & 0.049 & 0.945 & 0.975 & 0.684 & 0.338 \\
\hline$P$-value (Linear) & & 0.830 & 0.281 & 0.116 & 0.939 & 0.801 & 0.298 & 0.126 \\
\hline$P$-value (Quadratic) & & 0.249 & 0.443 & 0.056 & 0.584 & 0.848 & 0.541 & 0.829 \\
\hline \multicolumn{9}{|l|}{ Effect of Sex } \\
\hline Female & & $4375^{\mathrm{n}}$ & 84.2 & $1.9^{\mathrm{m}}$ & $3.8^{\mathrm{n}}$ & $0.086^{\mathrm{n}}$ & $25.8^{\mathrm{n}}$ & 0.590 \\
\hline Male & & $4887^{\mathrm{m}}$ & 81.3 & $1.7^{\mathrm{n}}$ & $5.2^{\mathrm{m}}$ & $0.108^{\mathrm{m}}$ & $29.4^{\mathrm{m}}$ & 0.600 \\
\hline$S E M$ & & 70.7 & 1.70 & 0.031 & 0.212 & 0.004 & 0.65 & 0.009 \\
\hline$P$-value (Sex) & & $<0.001$ & 0.247 & $<0.001$ & 0.001 & $<0.001$ & $<0.001$ & 0.443 \\
\hline \multicolumn{9}{|l|}{ Effect of $N A \times S e x$} \\
\hline \multirow[t]{2}{*}{ Control $0 \mathrm{mg} / \mathrm{kg}$} & Female & 4455 & 90.5 & 2.0 & 3.8 & 0.083 & 25.7 & 0.577 \\
\hline & Male & 4769 & 78.9 & 1.7 & 5.2 & 0.109 & 28.0 & 0.585 \\
\hline \multirow[t]{2}{*}{$100 \mathrm{mg} / \mathrm{kg}$} & Female & 4283 & 84.5 & 2.0 & 3.8 & 0.090 & 24.7 & 0.575 \\
\hline & Male & 4777 & 83.7 & 1.8 & 5.1 & 0.108 & 29.8 & 0.622 \\
\hline \multirow[t]{2}{*}{$300 \mathrm{mg} / \mathrm{kg}$} & Female & 4478 & 78.8 & 1.8 & 4.0 & 0.090 & 26.1 & 0.583 \\
\hline & Male & 5049 & 83.7 & 1.7 & 5.2 & 0.104 & 29.9 & 0.591 \\
\hline \multirow[t]{2}{*}{$1000 \mathrm{mg} / \mathrm{kg}$} & Female & 4284 & 83.0 & 1.9 & 3.5 & 0.080 & 26.8 & 0.624 \\
\hline & Male & 4952 & 79.0 & 1.6 & 5.4 & 0.110 & 29.8 & 0.602 \\
\hline$S E M$ & & 141.4 & 3.41 & 0.061 & 0.377 & 0.008 & 1.30 & 0.018 \\
\hline$P$-value (Interaction) & & 0.646 & 0.125 & 0.148 & 0.688 & 0.711 & 0.746 & 0.342 \\
\hline
\end{tabular}

$\mathrm{NA}=$ nonanoic acid; SEM = standard error of the mean. ${ }^{1}$ Relative organ weight (\%) was calculated as organ weight in g divided by BW in g. ${ }^{x y}$ Means within variable and factor with no common superscripts differed significantly at $P \leq 0.05$ (with Tukey's adjustment). ${ }^{\mathrm{mn}}$ Means within variable and factor with no common superscripts differed significantly at $P \leq 0.05$.

\section{Discussion}

Nonanoic acid (NA) has utility as a flavoring in poultry feed and to the authors knowledge, this study represents the first study to evaluate the tolerance and safety of the fatty acid to turkeys. A body of toxicological data on NA and the group of straight-chain aliphatic aldehydes, acids and their derivatives has been generated to support the use of the homologous series of flavorings in human food [6] [10]. These data can be extrapolated to poultry to support levels of 10 
and $18 \mathrm{mg} \mathrm{NA} / \mathrm{kg}$ complete feed as-fed for chickens and turkeys, respectively. However, considering that practical feed flavoring uses may well exceed these thresholds ( $>25 \mathrm{mg} / \mathrm{kg}$ complete feed as-fed), studies in the target animal are warranted to support the safety and tolerance of NA.

Recovery of NA ranged from $62 \%$ to $67 \%$ across the treated diets. Investigations using different solvent systems and extraction conditions revealed difficulties extracting NA from the diet. It is recognized that components such as starch in the feed matrix can bind, entrap or encapsulate chemically well-defined chemical substances such as NA which as a result, are poorly extracted from the diet [20].

The performance of the birds was maintained over the duration of the study with male turkeys as anticipated, displaying higher BW, ADG and ADFI compared to females. FCR was similar between the sexes during the grower and the whole feeding period consistent with NA being equally tolerated by males and females. There was a linear increase in ADG and ADFI with NA supplementation level in the diet which supports the known flavoring properties of the fatty acid.

Although a few changes were observed in the blood biochemistry results in birds fed NA-supplemented diets, no treatment-related responses were identified and all values fell within reference ranges found elsewhere in the literature [21] [22] [23]. Lower ALT values were consistently observed in birds fed diets supplemented but were not associated with any other effects on muscle or liver function. The higher albumin levels identified in female compared to male turkeys has previously been described [24]. Likewise, apart from some normal variations in male and female absolute and relative organ weights, there were no findings from macroscopic and histopathological examinations.

Overall, the results of the feeding study in turkeys indicate that NA is well-tolerated by turkeys at levels of up to $1000 \mathrm{mg} / \mathrm{kg}$ complete feed as-fed. These findings are consistent with the relatively simple structure of NA and its expected efficient metabolism in turkeys. On ingestion, NA is absorbed and $\beta$-oxidation occurs to yield acetate, which enters the citric acid cycle and is ultimately converted to carbon dioxide, water and energy [2] [6] [25].

There are only limited toxicological data on NA in the published literature, although several unpublished studies have been cited by authoritative and other scientific bodies [6] [25] [26]. Evaluations of NA for use as a flavoring in food have derived safe levels of use from the NOAEL of $120 \mathrm{mg} / \mathrm{kg}$ body weight/day allocated from a study on the structurally-related aldehyde, acetaldehyde in which fatty liver and associated inflammatory changes were observed at 500 $\mathrm{mg} / \mathrm{kg}$ body weight/day. There was no evidence of microscopic changes in the liver of turkeys fed up to $1000 \mathrm{mg} / \mathrm{kg}$ complete feed as-fed in the above-described study, equivalent to approximately $29 \mathrm{mg} / \mathrm{kg}$ body weight/day for male and female poults based on mean BW and ADFI at the day 56 of the study. On a body weight basis, the levels of NA used to supplement the diet of turkeys were considerably lower than the amounts reported to cause fatty liver 
effects in rats fed acetaldehyde $(29 \mathrm{mg} / \mathrm{kg}$ body weight/day vs. $>120 \mathrm{mg} / \mathrm{kg}$ body weight/day). Recognizing that extrapolation of data from laboratory animals to poultry is limited due to physiological differences between the species, the findings from the study described herein provide direct evidence of the tolerance of NA to turkeys.

Practical use levels of NA in feed are expected to be in the range of $25 \mathrm{mg} / \mathrm{kg}$ complete feed as-fed, or higher, where masking of strong off-flavors from other components of the diet is required. However, it is anticipated that commercial flavoring levels fall well below $1000 \mathrm{mg} \mathrm{NA} / \mathrm{kg}$ complete feed as-fed found to be well-tolerated by turkeys in this study, allowing a considerable margin of safety to be calculated.

\section{Conclusion}

The results of the 56-day feeding study in turkeys indicate that NA is well-tolerated by turkeys at levels of up to $1000 \mathrm{mg} / \mathrm{kg}$ complete feed as-fed, supporting use of the flavoring under practical conditions by the poultry industry.

\section{Acknowledgements}

The present work was funded by Anitox Ltd., Wellingborough, UK. Declarations of interest: none.

\section{Conflicts of Interest}

The authors declare no conflicts of interest regarding the publication of this paper.

\section{References}

[1] Council of Europe (1974) Natural Flavoring Substances, their Sources and Added Artificial Flavoring Substances. Maisonneuve S.A., Moulins-Les-Metz.

[2] JECFA (Joint FAO/WHO Expert Committee on Food Additives) (1998) Saturated Aliphatic Acyclic Linear Primary Alcohols, Aldehydes, and Acids. WHO Food Additive Series 40, World Health Organization, Geneva.

[3] U.S. Food and Drug Administration (2020) Title 21 of the Code of Federal Regulations. Food Additives Permitted for Direct Addition to Food for Human Consumption. Subpart F-Flavoring and Related Substances. Section 172.515 Synthetic Flavoring Substances and Adjuvants. U.S. Food and Drug Administration, Silver Spring.

[4] Berrie, A.M.M., Buller, D., Don, R. and Parker, W. (1979) Possible Role of Volatile Fatty Acids and Abscisic Acid in the Dormancy of Oats. Plant Physiology, 63, 758-764. https://doi.org/10.1104/pp.63.4.758

[5] Marin Municipal Water (2010) Marin Municipal Water District Vegetation Management Plan. Herbicide Risk Assessment. Draft 1/1/2010. Chapter 7-Pelargonic Acid. Pesticide Research Institute. Berkley, CA, 1-37. https://www.marinwater.org/documentcenter/view/252

[6] Johnson Jr., W., Heldreth, B., Bergfeld, W.F., Belsito, D.V., Klaassen, C.D., Hill, R., et al. (2011) Final Report of the Cosmetic Ingredient Review Expert Panel on the 
Safety Assessment of Pelargonic Acid (Nonanoic Acid) and Nonanoate Esters. International Journal of Toxicology, 30, 228S-269S. https://doi.org/10.1177\%2F1091581811428980

[7] European Commission (2020) Annex I: List of additives. European Union Register of Feed Additives pursuant to Regulation (EC) No 1831/2003. Publications Office of the European Union, Luxembourg.

[8] Infiniti Research Limited (2017) Global Feed Flavors and Sweeteners Market 2017-2021. Report ID: 5256427, Infiniti Research Limited, London.

https://www.reportlinker.com/p05256427/Global-Feed-Flavors-and-Sweeteners-Ma rket.html

[9] Markets and Market Research (2017) Feed Flavors and Sweeteners Market by Type (Feed Flavors and Feed Sweeteners), Livestock (Ruminants, Swine, Poultry, Aquatic Animals), Form (Dry and Liquid), Source (Natural and Synthetic) and Region-Global Forecast to 2022. Report No. AGI 5603. Markets and Market Research, India.

[10] European Food Safety Authority Panel on Additives and Products of Substances used in Animal Feed (FEEDAP) (2013) Scientific Opinion on the Safety and Efficacy of Straight-Chain Primary Aliphatic Alcohols/Aldehydes/Acids, Acetals and Esters with Esters Containing Saturated Alcohols and Acetals Containing Saturated Aldehydes (Chemical Group 1) When Used as Flavorings for All Animal Species.. EFSA Journal, 11, Article No. 3169. https://doi.org/10.2903/j.efsa.2013.3169

[11] Cave, N.A.G. (1982) Effect of Dietary Short- and Medium-Chain Fatty Acids on Feed Intake by Chicks. Poultry Science, 61, 1147-1153.

https://doi.org/10.3382/ps.0611147

[12] U.S. Food and Drug Administration, Center for Veterinary Medicine (2009) Guidance for Industry: Target Animal Safety for Veterinary Pharmaceutical Products. VICH GL43, No. 185, Docket No. FDA-2007-D-0430, U.S. Food and Drug Administration, Silver Spring.

[13] European Food Safety Authority Panel on Additives and Products of Substances used in Animal Feed (FEEDAP) (2017) Scientific Opinion on the Safety of Feed Additives for the Target Species. EFSA Journal, 15, Article No. 5021.

[14] European Commission (2007) Recommendation 2007/526. Guidelines for the Accommodation and Care of Animals used for Experimental and other Scientific Purposes. Official Journal of the European Union, L197/1.

[15] European Commission (2010) Directive 2010/63/EU of the European Parliament and of the Council of 22 September 2010 on the Protection of Animals used for Scientific Purposes. Official Journal of European Union, L276/53.

[16] Royal Decree (2005) Spanish Ministry of Agriculture, Fishing and Food. 16092 Royal Decree 1084/2005, 16 September, Regulation of Poultry Production for Meat.

[17] Turkeys, A. (2012) Feed Programs for BUT Commercial Turkeys-Key Points. Aviagen Amended 2009.

[18] AOAC (2000) Official Methods of Analysis. 18th Edition, Association of Official Analytical Chemists, Washington DC.

[19] SAS for Windows (2002) SAS Software Version 9.4. SAS, Cary.

[20] Naknean, P. and Meenune, M. (2010) Factors Affecting Retention and Release of Flavour Compounds in Food Carbohydrates. International Food Research Journal, 17, 23-34.

[21] Bounous, D.I., Wyatt, R.D., Gibbs, P.S., Kilburn, J.V. and Quist, C.F. (2000) Normal Hematologic and Serum Biochemical Reference Intervals for Juvenile Wild Turkeys. 
Journal of Wildlife Diseases, 36, 393-396.

https://doi.org/10.7589/0090-3558-36.2.393

[22] Szabó, A., Mezes, M., Horn, P., Sütő, Z., Bázár, G.Y. and Romvari, R. (2005) Developmental Dynamics of some Blood Biochemical Parameters in the Growing Turkey (Meleagris gallopavo). Acta Veterinaria Hungarica, 53, 397-409.

https://doi.org/10.1556/avet.53.2005.4.1

[23] Priya, M. and Gomathy, V.S. (2008) Hematological and Blood Biochemicals in Male and Female Turkeys of Different Age Groups. Tamilnadu Journal of Veterinary \& Animal Sciences, 4, 60-68.

[24] Gattani, A., Pathak, A., Kumar, A., Mishra, V. and Bhatia, J.S. (2016) Influence of Season and Sex on Hemato-Biochemical Traits in Adult Turkeys under Arid Tropical Environment. Veterinary World, 9, 530-534.

https://doi.org/10.14202/vetworld.2016.530-534

[25] U.S. Environmental Protection Agency (2004) Ammonium Nonanoate; Notice of Filing a Pesticide Petition to Establish a Tolerance for a Certain Pesticide Chemical in or on Food. Federal Register, 69, 12670-12676.

[26] U.S. Environmental Protection Agency (1997) Mycogen Corporation; Notice of Filing a Pesticide Tolerance Petition. Federal Register, 62, 3688-3691. 